Louisiana State University

LSU Digital Commons

3-1-2007

\title{
Human genomic DNA quantitation system, H-Quant: Development and validation for use in forensic casework
}

Jaiprakash G. Shewale

ReliaGene Technologies, Inc.

Elaine Schneida

ReliaGene Technologies, Inc.

Jonathan Wilson

ReliaGene Technologies, Inc.

Jerilyn A. Walker

Louisiana State University

Mark A. Batzer

Louisiana State University

See next page for additional authors

Follow this and additional works at: https://digitalcommons.Isu.edu/biosci_pubs

\section{Recommended Citation}

Shewale, J., Schneida, E., Wilson, J., Walker, J., Batzer, M., \& Sinha, S. (2007). Human genomic DNA quantitation system, H-Quant: Development and validation for use in forensic casework. Journal of Forensic Sciences, 52 (2), 364-370. https://doi.org/10.1111/j.1556-4029.2006.00369.x

This Article is brought to you for free and open access by the Department of Biological Sciences at LSU Digital Commons. It has been accepted for inclusion in Faculty Publications by an authorized administrator of LSU Digital Commons. For more information, please contact ir@lsu.edu. 


\section{Authors}

Jaiprakash G. Shewale, Elaine Schneida, Jonathan Wilson, Jerilyn A. Walker, Mark A. Batzer, and Sudhir K. Sinha 


\author{
Jaiprakash G. Shewale, ${ }^{1}$ Ph.D.; Elaine Schneida, ${ }^{1}$ B.S.; Jonathan Wilson, ${ }^{1}$ B.S.; Jerilyn A. Walker, ${ }^{2}$ M.S.; \\ Mark A. Batzer, ${ }^{2}$ Ph.D.; and Sudhir K. Sinha, ${ }^{1}$ Ph.D.
}

\title{
Human Genomic DNA Quantitation System, H-Quant: Development and Validation for Use in Forensic Casework
}

\begin{abstract}
The human DNA quantification (H-Quant) system, developed for use in human identification, enables quantitation of human genomic DNA in biological samples. The assay is based on real-time amplification of $A l u \mathrm{Yb} 8$ insertions in hominoid primates. The relatively high copy number of subfamily-specific Alu repeats in the human genome enables quantification of very small amounts of human DNA. The oligonucleotide primers present in H-Quant are specific for human DNA and closely related great apes. During the real-time PCR, the SYBR ${ }^{\circledR}$ Green I dye binds to the DNA that is synthesized by the human-specific AluYb8 oligonucleotide primers. The fluorescence of the bound SYBR ${ }^{\circledR}$ Green I dye is measured at the end of each PCR cycle. The cycle at which the fluorescence crosses the chosen threshold correlates to the quantity of amplifiable DNA in that sample. The minimal sensitivity of the H-Quant system is $7.6 \mathrm{pg} / \mu \mathrm{L}$ of human DNA. The amplicon generated in the $\mathrm{H}$-Quant assay is $216 \mathrm{bp}$, which is within the same range of the common amplifiable short tandem repeat (STR) amplicons. This size amplicon enables quantitation of amplifiable DNA as opposed to a quantitation of degraded or nonamplifiable DNA of smaller sizes. Development and validation studies were performed on the 7500 real-time PCR system following the Quality Assurance Standards for Forensic DNA Testing Laboratories.
\end{abstract}

KEYWORDS: forensic science, real-time PCR, human identification, polymerase chain reaction, DNA typing, DNA quantitation, Alu repeats, AluYb8, SYBR ${ }^{\circledR}$ green I, human DNA

Short tandem repeat (STR) loci distributed on autosomal and Ychromosomes are now routinely used in forensic laboratories and court systems (1-4). In general, the STR profile from an evidence sample is compared with the profiles from known individuals to determine the contribution of a known individual's DNA to the evidence sample. DNA analysis of forensic samples typically involves isolation of the DNA, quantitation for human DNA, amplification of highly polymorphic STRs, separation of the amplified fragments, genotyping, and result interpretation. Within this process, the quantitation of human-specific DNA in the extract obtained from the biological sample is a crucial step. The intention of human DNA quantitation for forensic samples is to determine the amount of extracted DNA required for multiplex STR systems to obtain an interpretable STR profile with allele peak heights within the resolution range for unambiguous interpretation. Quantitation of human DNA is also useful in making decisions for using the low copy number DNA analysis strategies in order to obtain an interpretable STR profile (5). Forensic evidence samples frequently undergo environmental insults and are often contaminated with nonhuman biological material; thus, re-

${ }^{1}$ ReliaGene Technologies, Inc., 5525 Mounes St. Suite 101, New Orleans, LA 70123.

${ }^{2}$ Department of Biological Sciences, Biological Computation, and Visualization Center, Center for BioModular Multi-Scale Systems, Louisiana State University, 202 Life Sciences Building, Baton Rouge, LA 70803.

Received 23 April 2005; and in revised form 3 Dec. 2005, 31 May and 14 Sept. 2006; accepted 1 Oct. 2006; Published 6 Feb. 2007. agents like PicoGreen ${ }^{\circledR}$ are inappropriate for the quantitation of DNA in forensic evidence samples. The accuracy of the quantitation system is, therefore, important in forensic DNA analysis.

Quantiblot ${ }^{\circledR}$, a system based on hybridization of a biotynylated probe to DNA samples immobilized on a nylon membrane, has routinely been used for a long time in forensic laboratories (6). AluQuant ${ }^{\circledR}$, yet another commercially available system, is based on the hybridization of a proprietary probe to highly repetitive sequences on human chromosomes (7). The detection limit for these assay methods is about $0.1-0.15 \mathrm{ng}$ of human DNA. DNA templates of less than $100 \mathrm{pg}$ may yield an interpretable STR profile, either complete, or partial. Thus, the possibility of losing valuable information exists due to the decision not to amplify the samples that do not exhibit quantitation values for human DNA by such methods. Highly sensitive methods for quantitation of human DNA based on the amplification of $A l u$ repeats have previously been reported $(8,9)$. These methods are based on the measurement of amplification products after a specific number of cycles because after a certain number of cycles, product production may near the saturation point (e.g., fluorescence curve ceases to be exponential), causing an inaccurate quantity of DNA to be assumed.

In recent years, real-time PCR assays for quantitation of nucleic acids have proved to be very useful. This is because a quantitative relationship exists, in theory, between the amount of target sequence at the start and the amount of PCR product at any given cycle before reaching saturation. The advantages of real-time quantitation assays include a greater dynamic quantitation range, 
sensitivity, rapidity, automated analysis, measurement of amplifiable DNA, and cost-effectiveness. Several real-time PCR methods have been reported in the literature for quantitation of human DNA (10-15). Quantifiler ${ }^{\mathrm{TM}}$ systems for the quantitation of human and human male DNA are commercially available from Applied Biosystems (14). These systems are supported on the 7000, 7900 HT, and 7500 Sequence Detection Systems (Applied Biosystems) for forensic applications.

We have reported a method for quantitation of human DNA in biological materials using inter-Alu and intra-Alu PCR (15). Certain $A l u$ repeats are stable insertions and hence unique nuclear markers that provide increased species specificity, even among higher primates, and are ideally suited for human identity testing. The Alu family of interspersed repeats is the most successful of the mobile genetic elements in terms of integration and copy number within primate genomes. Assay methods targeting certain Alu element subfamilies provide high sensitivity because of their high copy numbers in the human genome (16). Alu subfamilies that are present in the human genome but are essentially absent from nonhuman primates are now known (16). Here, we report an improved assay method called human DNA quantification (H-Quant) that can be used for quantitation of human DNA in forensic samples using the 7500 real-time PCR System (Applied Biosystems, Foster City, CA). The H-Quant assay method is based on the amplification of AluYb8 elements (17).

\section{Materials and Methods}

Oligonucleotide primers were synthesized and obtained from Operon (Alameda, CA). Ten times PCR buffer, AmpliTaq Gold ${ }^{\text {TM }}$ DNA polymerase, and AmpFlSTR ${ }^{\circledR}$ COfiler ${ }^{\mathrm{TM}}$ were obtained from Applied Biosystems (Foster City, CA). SYBR ${ }^{\circledR}$ Green I nucleic acid gel stain dye was obtained from Molecular Probes (Eugene, OR). Reference dye for quantitative PCR and bovine serum albumin (BSA) fraction V were obtained from Sigma Chemical Co. (St. Louis, MO). Human male genomic DNA was obtained from Novagen (Madison, WI). All other chemicals used in this study were of analytical grade.

\section{Extraction and Quantitation of DNA}

The DNA from anonymous donor samples was obtained from blood drawn in EDTA vacutainer tubes or buccal swabs and was extracted either by Chelex ${ }^{\circledR}$ (18), BioRobot EZ1 (Qiagen, Valencia, CA), or QIAamp ${ }^{\circledR}$ MiniKit (Qiagen) procedures. The quantity of human DNA was determined by the Quantifiler ${ }^{\mathrm{TM}}$ human DNA quantitation kit (Applied Biosystems). DNA in the samples used for sensitivity studies was prepared by serial dilutions using $10 \mathrm{mM}$ Tris- $\mathrm{HCl}, \mathrm{pH}$ 8.0, containing $0.01 \mathrm{mM}$ EDTA.

\section{Real-Time PCR Amplification}

Amplification reactions contained $5.0 \mu \mathrm{L}$ of $\mathrm{H}$-Quant primer mix, $17.8 \mu \mathrm{L}$ of $\mathrm{H}$-Quant reaction mix, $0.2 \mu \mathrm{L}$ of AmpliTaq $\operatorname{Gold}^{\mathrm{TM}}(5 \mathrm{U} / \mu \mathrm{L})$, and $2.0 \mu \mathrm{L}$ of DNA sample. The volume of the DNA template was kept constant at $2.0 \mu \mathrm{L}$. This is to ensure compatibility with the real-time instrument software (7500 System SDS Software v1.2.3f2, Applied Biosystems). The software provides the results as a concentration of $\mathrm{DNA} / \mu \mathrm{L}$ of the template solution. The amount of template DNA, therefore, is expressed as a concentration rather than a total input quantity in the text. The $\mathrm{H}$-Quant primer mix was prepared by combining the forward and reverse primers $(6.0 \mu \mathrm{M})$ in $100 \mathrm{mM}$ Tris- $\mathrm{HCl}, \mathrm{pH} 8.3$, containing $500 \mathrm{mM} \mathrm{KCl}, 15 \mathrm{mM} \mathrm{MgCl}_{2}$, and $0.01 \%$ gelatin. The primers were selected and designed based on the published sequences to obtain a $216 \mathrm{bp}$ fragment (15). The H-Quant reaction mix contained SYBR $^{\circledR}$ Green I dye $(\times 0.35)$, reference dye $(\times 0.55)$, BSA $(7 \mu \mathrm{g} / \mathrm{mL})$, dNTPs $(1.12 \mathrm{mM})$ in $10 \mathrm{mM}$ Tris- $\mathrm{HCl}$, pH 8.3 containing $50 \mathrm{mM} \mathrm{KCl}, 1.5 \mathrm{mM} \mathrm{MgCl}_{2}$, and $0.001 \%$ gelatin. The final concentrations of the reagents in the reaction were: buffer $(\times 1)$, primers $(1.2 \mu \mathrm{M})$, dNTPs $(0.8 \mathrm{mM}), \mathrm{MgCl}_{2}(3.0 \mathrm{mM})$, BSA $(0.25 \mu \mathrm{g}), \mathrm{SYBR}^{\circledR}$ Green I dye $(\times 0.25)$, and reference dye $(\times 0.2)$. Amplification reactions were performed in a 7500 realtime PCR system (Applied Biosystems) following the manufacturer's instruction under the following: $95^{\circ} \mathrm{C}, 10 \mathrm{~min} ; 35$ cycles of $95^{\circ} \mathrm{C}, 15 \mathrm{sec}$, and $72^{\circ} \mathrm{C}, 1 \mathrm{~min}$. A standard curve was constructed by using serial dilutions of human male genomic DNA (Novagen) ranging from $7.6 \mathrm{pg} / \mu \mathrm{L}$ to $50 \mathrm{ng} / \mu \mathrm{L}$. The standards were included with each batch of quantitation reaction. The data were analyzed using 7500 System SDS Software v1.2.3f2 (Applied Biosystems).

\section{Amplification for STRs}

The amplifications using the AmpFlSTR ${ }^{\circledR}$ COfiler $^{\mathrm{TM}}$ PCR amplification kit were performed as recommended by the manufacturer using GeneAmp ${ }^{\circledR}$ PCR System 9700 (3). The amplified products were analyzed on a 3100 Genetic Analyzer as described in the instruction manual. The data were analyzed using Genotyper $^{\circledR}$ software (Applied Biosystems).

\section{Results and Discussion}

During real-time PCR, accumulation of the PCR product is monitored with each cycle. In the H-Quant assay, accumulated PCR product is measured by the fluorescence resulting from the binding of SYBR ${ }^{\circledR}$ Green I dye to the amplified products. Very little change in the fluorescence is expected at the initial cycles of PCR and is used to determine the baseline for the amplification plot. The threshold fluorescence signal is the level of fluorescence intensity above background. In general, the threshold is set in the exponential phase of the amplification for accurate quantitation results. Thus, the samples with low amounts of DNA template would cross the threshold at a higher cycle number. The cycle at which the fluorescence crosses the threshold value is termed as cycle threshold or $C_{\mathrm{T}}$. The higher the $C_{\mathrm{T}}$ value, the lesser the quantity of template DNA. The efficiency of the H-Quant assay was measured in terms of the $C_{\mathrm{T}}$ value. In the H-Quant system, a high $C_{\mathrm{T}}$ value can be measured without interference from the background, thus yielding a sensitivity as low as $7.6 \mathrm{pg} / \mu \mathrm{L}$ of DNA.

The Quality Assurance Standards for Forensic DNA Laboratories were followed for conducting validation studies (19). The experiments are described in a sequential order and the values established in the previous experiment are maintained throughout the remaining experiments.

\section{Optimization of PCR}

In a real-time PCR that is targeted to detect the products using intercalating dyes like SYBR ${ }^{\circledR}$ Green I, any "primer-dimer," or primer adducts contribute to the observed fluorescence. This phenomenon is commonly observed when high amounts of primers are incorporated. Using lower amounts of primers decreases the sensitivity. The quantity of primers, therefore, is a critical parameter in optimizing the real-time PCR assay. The contribution of dimer and primer adducts toward the fluorescence is determined by the amount of fluorescence provided by a no template DNA control (NTC). NTC or amplification of a negative control was 


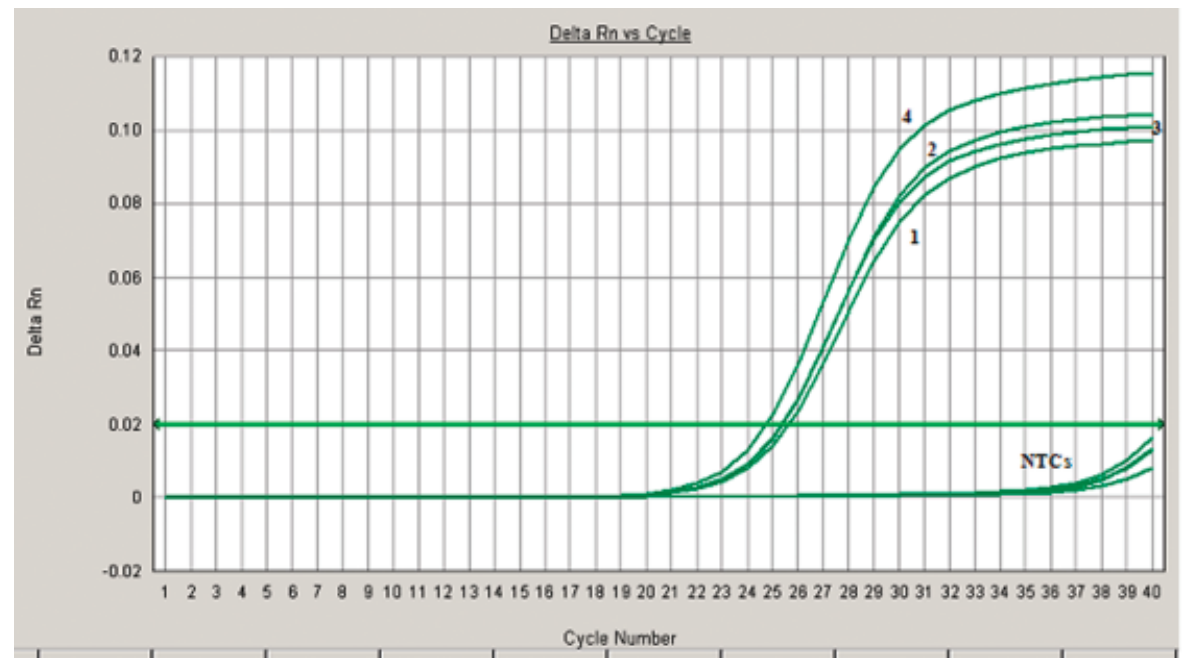

FIG. 1-Two microliters of human DNA (200 pg/ $\mu L$ ) was amplified using 0.6 (line 1), 0.8 (line 2), 1.0 (line 3), and $1.2 \mu M$ primers (line 4) in the human DNA quantification (H-Quant) assay. NTCs indicate no template controls. The threshold value is indicated by a solid horizontal line with arrows.

incorporated into each experiment. The primer pair titration was tested at $0.6,0.8,1.0$, and $1.2 \mu \mathrm{M}$ (final concentration) using a DNA template ranging from $20.0 \mathrm{pg} / \mu \mathrm{L}$ to $2.0 \mathrm{ng} / \mu \mathrm{L}$ from a human DNA sample. The primer concentration did not influence the assay significantly at any concentration of template DNA. The results from $200 \mathrm{pg} / \mu \mathrm{L}$ of human DNA are presented in Fig. 1 as representative data from the experimental set. An increase in the primer concentration from 0.6 to $1.2 \mu \mathrm{M}$ decreased the $C_{\mathrm{T}}$ value from 25.7 to 24.9 . Primers at $1.2 \mu \mathrm{M}$ were used in the $\mathrm{H}$-Quant assay.

The concentration of $\mathrm{MgCl}_{2}$ was varied from 1.5 to $6.0 \mathrm{mM}$. Five human DNA samples with concentrations ranging from $7.6 \mathrm{pg} / \mu \mathrm{L}$ to $50.0 \mathrm{ng} / \mu \mathrm{L}$ were used. The results from $50 \mathrm{ng} / \mu \mathrm{L}$ of template DNA are summarized in Fig. 2 as representative data from the experimental set. The efficiency of the assay was increased when the $\mathrm{MgCl}_{2}$ concentration increased from $1.5 \mathrm{mM}$ to $3.0 \mathrm{mM}$; the $C_{\mathrm{T}}$ value decreased from 16.7 to 15.2 . However, the sensitivity decreased slightly when the concentration of the $\mathrm{MgCl}_{2}$ was higher than $3.0 \mathrm{mM}$. Similar results were obtained for the five human DNA samples and all template DNA concentrations. $\mathrm{MgCl}_{2}$ at $3.0 \mathrm{mM}$ was used in the H-Quant assay.

Higher concentrations of dNTPs are precursors for the synthesis of DNA and can inhibit the PCR either by entrapment of $\mathrm{Mg}^{2+}$ ions or substrate inhibition of DNA polymerase $(20,21)$. The optimal concentration of dNTPs in the H-Quant assay was determined by amplification of five human DNA samples $(7.67 \mathrm{pg} / \mu \mathrm{L}$ to $50.0 \mathrm{ng} / \mu \mathrm{L}$ ) at $0.4,0.8,1.2$, and $1.6 \mathrm{mM}$ of dNTPs. The 0.4 and $0.8 \mathrm{mM}$ tests gave very similar $C_{\mathrm{T}}$ values; however, the NTC gave a slightly higher background reading with $0.4 \mathrm{mM}$ dNTPs (data not shown). Increasing the dNTPs to 1.2 and $1.6 \mathrm{mM}$ exhibited an increased $C_{\mathrm{T}}$ value, indicating an inhibitory effect on the assay; the $\underline{C}_{\mathrm{T}}$ values observed for $620 \mathrm{pg} / \mu \mathrm{L}$ of human DNA using 0.4 , $0.8,1.2$, and $1.6 \mathrm{mM}$ dNTPs were 20.9, 20.8, 21.4, and 23.5, respectively. dNTPs at $0.8 \mathrm{mM}$ were used in the H-Quant assay.

In the H-Quant assay, SYBR ${ }^{\circledR}$ Green I is the reporter dye. In addition, a reference dye (proprietary dye obtained from Sigma) is incorporated into the assay. The reference dye enables normalization of the fluorescence signal generated by the reporter dye.

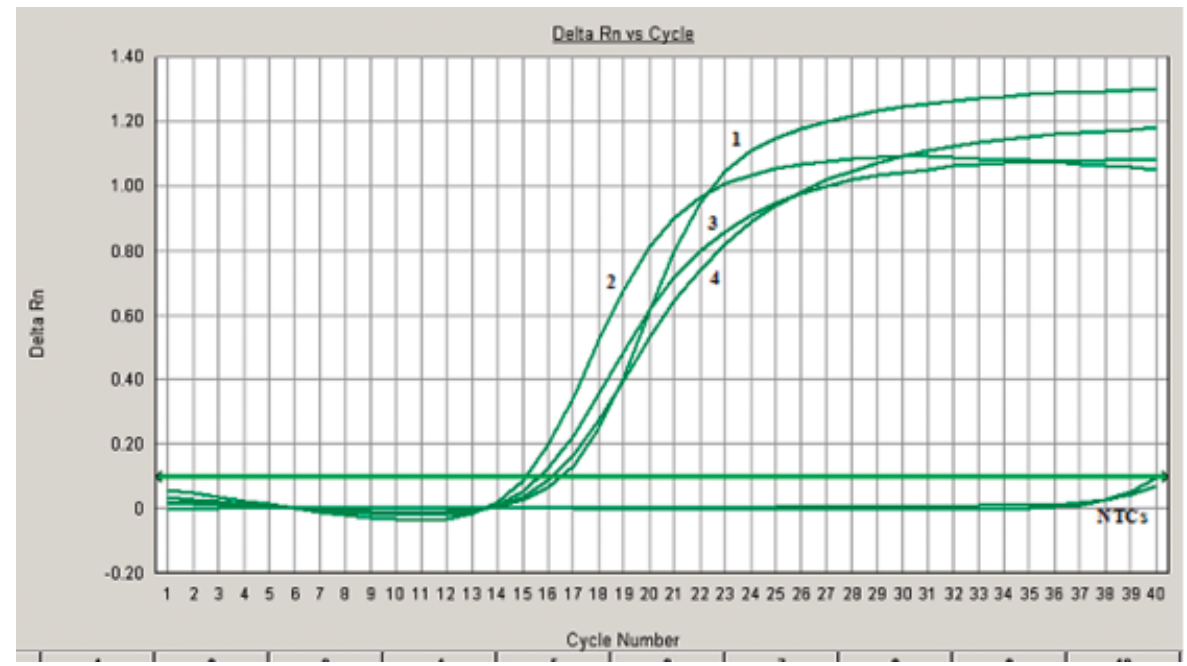

FIG. 2-Effect of $\mathrm{MgCl}_{2}$ on the quantitation of DNA using the human DNA quantification (H-Quant) assay. $2.0 \mu L$ of human DNA (50 ng/ $L$ L) was amplified with 1.5 (line 1), 3.0 (line 2), 4.5 (line 3), and $6.0 \mathrm{mM} \mathrm{MgCl}$ (line 4). NTCs indicate no template controls. The threshold value is indicated by a solid horizontal line with arrows. 


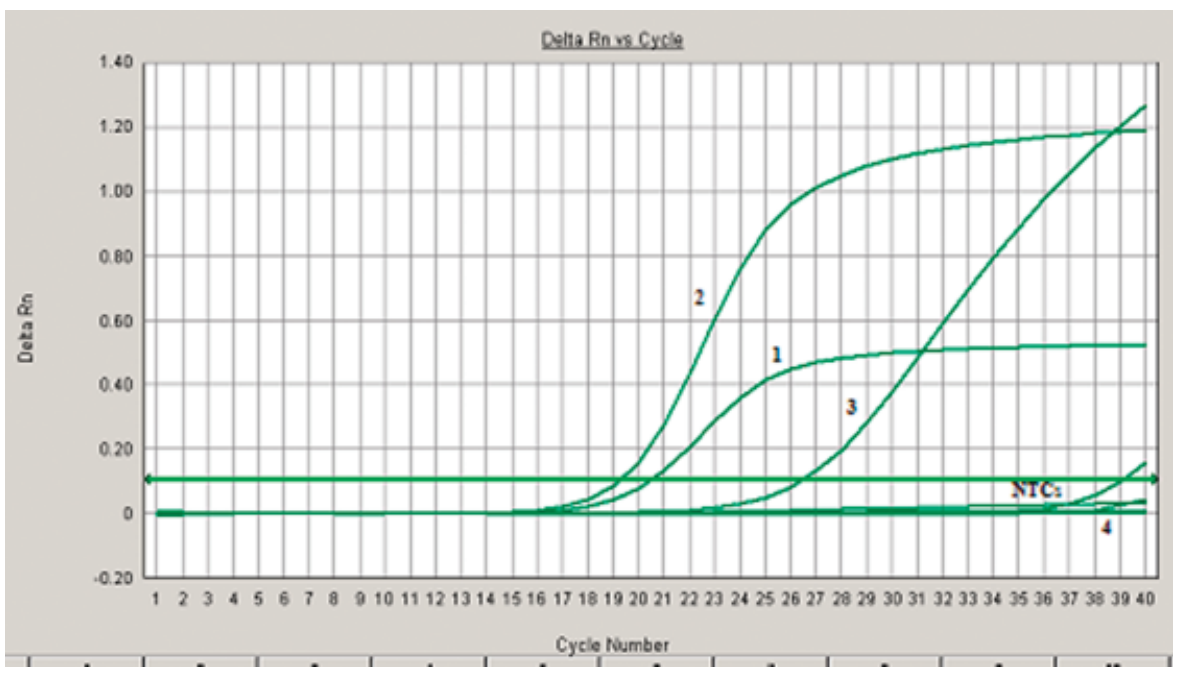

FIG. 3-Two microliters of human DNA $(620 \mathrm{pg} / \mu \mathrm{L})$ was amplified using 0.125 (line 1), 0.25 (line 2), 0.5 (line 3), and $\times 1.0$ concentration (line 4) of the $S Y B R^{\mathbb{R}}$ Green I dye in the human DNA quantification (H-Quant) assay. The concentration of the reference dye in the assay was $\times 0.2 . N T C s$ indicate no template controls. The threshold value is indicated by a solid horizontal line with arrows.

The concentrations of these dyes would, therefore, contribute to the sensitivity of the H-Quant assay. SYBR ${ }^{\circledR}$ Green I dye is obtained as $10,000 \times$ in dimethyl sulfoxide (DMSO), whereas the reference dye is provided as a $100 \times$ solution. Five human DNA samples of concentrations ranging from $7.6 \mathrm{pg} / \mu \mathrm{L}$ to $50.0 \mathrm{ng} / \mu \mathrm{L}$ were amplified at different concentrations of SYBR ${ }^{\circledR}$ Green I and the reference dye. The concentration of SYBR ${ }^{\circledR}$ Green I was investigated at $\times 0.125, \times 0.25, \times 0.5$, and $\times 1$ and the reference dye at $\times 0.2, \times 0.5$, and $\times 1$ (Figs. 3 and 4 ). Both the sensitivity and magnitude of the exponential phase increased when the concentration of SYBR ${ }^{\circledR}$ Green I was increased from $\times 0.125$ to $\times 0.25$ (Fig. 3). Further increase to $\times 0.5$ inhibited the PCR reaction significantly; complete inhibition was observed at IX concentration. Decreasing the amount of reference dye from $\times 1$ to $\times 0.5$ and $\times 0.2$ increased both the sensitivity and geometric phase of the PCR curve (Fig. 4). Thus, a combination of $\times 0.25 \mathrm{SYBR}^{\circledR}$ Green I dye and $\times 0.2$ reference dye gave the best results as judged by the $C_{\mathrm{T}}$ values and geometric phase and was used in the H-Quant assay.

BSA is generally incorporated into the PCR reaction mixture as an additive to aid in the amplification of samples containing small amounts of DNA or possibly degraded DNA samples. The concentration of BSA to add to the reaction mixture was determined by a series of experiments that included $0.0,0.125,0.25,0.5$, and $0.75 \mu \mathrm{g}$ of BSA fraction $\mathrm{V}$ and using DNA template ranging from $7.6 \mathrm{pg}$ to $50.0 \mathrm{ng}$. Incorporation of BSA up to $0.25 \mu \mathrm{g}$ exhibited a slight increase in sensitivity; the $C_{\mathrm{T}}$ value decreased by 0.7 cycle for $620 \mathrm{pg} / \mu \mathrm{L}$ of template DNA. Higher amounts of BSA, however, showed a steady increase in $C_{\mathrm{T}}$ (data not shown). $0.25 \mu \mathrm{g}$ of BSA was incorporated into the H-Quant assay.

The AmpliTaq ${ }^{\mathrm{TM}}$ Gold DNA Polymerase was incorporated at $0.5,1.0$, and $1.5 \mathrm{U}$ and using DNA template ranging from $200 \mathrm{pg}$ to $50 \mathrm{ng}$. One unit of the DNA polymerase showed a lower $C_{\mathrm{T}}$ value, indicating greater sensitivity compared with those samples

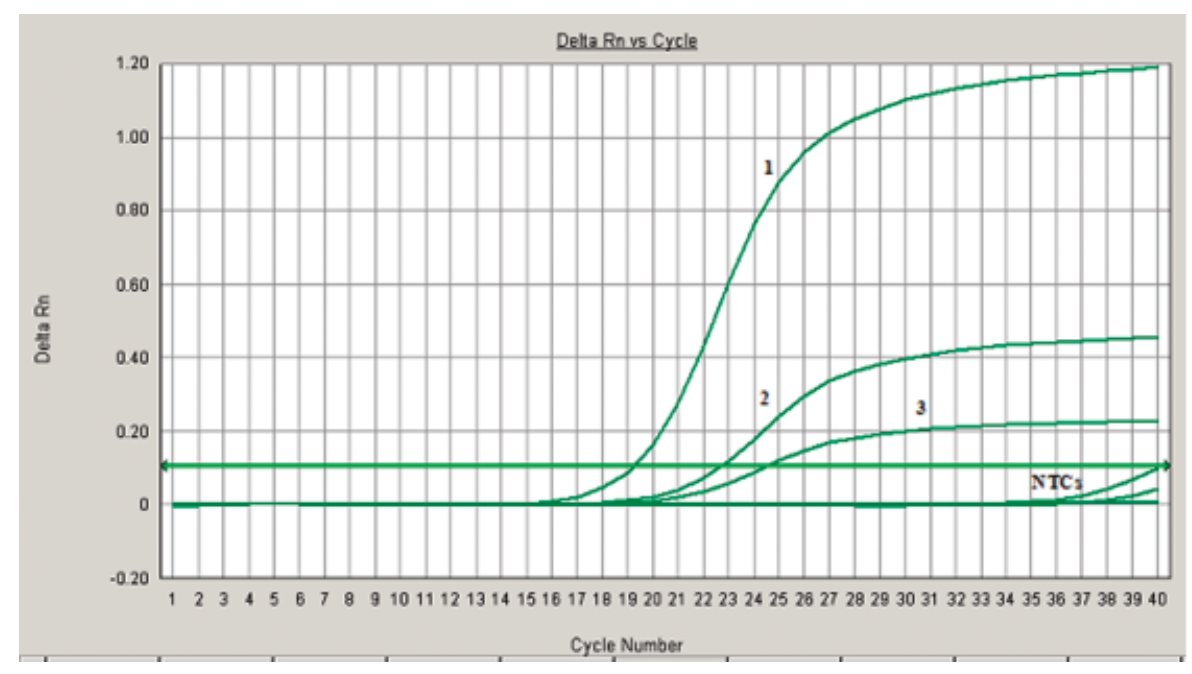

FIG. 4-Two microliters of human DNA $(620 \mathrm{pg} / \mu \mathrm{L})$ was amplified using 0.2 (line 1$), 0.5$ (line 2 ), and $\times 1.0$ concentration (line 3 ) of the reference dye in the human DNA quantification (H-Quant) assay. The concentration of the SYBR ${ }^{\circledR}$ Green I dye in the assay was $\times 0.5$. NTCs indicate no template controls. The threshold value is indicated by a solid horizontal line with arrows. 
tested with $0.5 \mathrm{U}$ of the DNA polymerase (data not shown). When $1.5 \mathrm{U}$ of the polymerase were used, the fluorescence signal from the NTC increased significantly, although a slight increase in sensitivity in the detection of samples was observed (data not shown). A balance between the sensitivity of the assay and minimal background reading was observed using $1.0 \mathrm{U}$ of AmpliTaq ${ }^{\mathrm{TM}}$ Gold DNA Polymerase.

\section{Nonhuman Species}

Several different nonhuman species were tested using 2-4 ng of DNA template with the H-Quant assay in order to determine the human specificity of the AluYb8 primers. The different specimens included DNA from cat, dog, sheep, orangutan, gorilla, Escherichia coli (ATCC\# 700927D), Staphyloccus aureus subsp. aureus (ATCC\# 35556D), Neisseria gonorrhoeae (ATCC\# 700825D), Candida albicans (ATCC 14053D), and hepatitis B virus (ADW) (ATCC 45020D). The DNA from cat, dog, orangutan, gorilla, E. coli, S. aureus subsp. aureus, N. gonorrhea, C. albicans, and Hepatitis B virus (ADW) did not yield any products. Of the two sheep samples tested, sheep-1 did not yield an amplified product; however, sheep-2 gave a $C_{\mathrm{T}}$ value such that the quantitative value was $0.45 \mathrm{pg} / \mu \mathrm{L}$. The sheep- 2 sample yielded a concentration of $4.3 \mathrm{ng} / \mu \mathrm{L}$ of DNA when quantitated using the Pico Green ${ }^{\circledR}$ reagent and a Victor3 fluorescence reader (Perkin Elmer, Wellesley, MA), a quantitation method that is not human specific (22). Thus, the H-Quant assay for the sheep-2 sample yielded results that were 9555 times less than the nonspecific quantitation method. An extremely low level of cross-amplification has been observed for some mobile element-based genetic systems because of the ubiquitous nature of 7SL- and tRNA-related SINE families and this factor typically does not interfere with the assay used for human DNA (15). The nonhuman primate species investigated in the present study provided some results (orangutan, $0.28 \mathrm{pg} / \mu \mathrm{L}$, and gorilla, $34.3 \mathrm{pg} / \mu \mathrm{L}$ ) using the H-Quant assay. Thus, the Alu Yb8 primers in the H-Quant assay are specific for human DNA and some great apes. The human DNA-specific AluQuant ${ }^{\mathrm{TM}}$ Probe Mix (Promega Corporation, Madison, WI) exhibited a low level of amplification with the DNA from mouse, yeast, E. coli (strain B), and C. perfringens (7). A low level of amplification up to $0.07 \%$ for some animal species is observed using the Ya5 subfamily Alu (plasmid pPD39)-specific primers (10).

\section{Sensitivity Study}

The sensitivity of the H-Quant assay system was investigated by quantitation of human DNA samples with quantities of DNA ranging from $5.0 \mathrm{pg} / \mu \mathrm{L}$ to $24.4 \mathrm{ng} / \mu \mathrm{L}$ (Fig. 5). As expected, the $C_{\mathrm{T}}$ value increased progressively with a decrease in the amount of human DNA. In a separate experiment, the quantity of DNA was further decreased to $2.0 \mathrm{pg} / \mu \mathrm{L}$ (data not shown). The results indicate that the $\mathrm{H}-\mathrm{Quant}$ assay is highly sensitive and exhibits a very dynamic range. Although it was possible to detect and quantitate $2.0 \mathrm{pg} / \mu \mathrm{L}$ of DNA, a greater margin of error existed at lower concentrations of DNA. The sensitivity of the H-Quant assay was determined at $7.6 \mathrm{pg} / \mu \mathrm{L}$.

\section{Precision and Reproducibility Study}

A total of 20 runs were performed at different times and on different days using the human DNA sample at concentrations ranging from $8 \mathrm{pg} / \mu \mathrm{L}$ to $50 \mathrm{ng} / \mu \mathrm{L}$. A calibration curve was generated for each experiment. The precision of the H-Quant assay was evaluated by the variation in the values of slope for the calibration curve. The slope values ranged between -4.15 and -3.30 . For these set of runs, the average slope value was -3.722 and the standard deviation was 0.288 . Besides the variability inherent in pipetting, the constitutions of PCR reagents contribute to the slope value of the calibration curve. It is, therefore, recommended to derive an acceptable range for the slope value for each batch of primer mix and reaction mix.

\section{Concordance Study}

Sixteen different human samples were quantified using the $\mathrm{H}$ Quant assay and the Quantifiler ${ }^{\mathrm{TM}} \mathrm{H}$-Quant kit. The results of these sixteen samples from the two different assays were compared. The results obtained from the H-Quant human DNA quantitation assay and the Quantifiler ${ }^{\mathrm{TM}}$ Human DNA Quantitation kits are summarized in Table 1 . The quantitation values obtained from the two systems were comparable. However, the Quantifiler

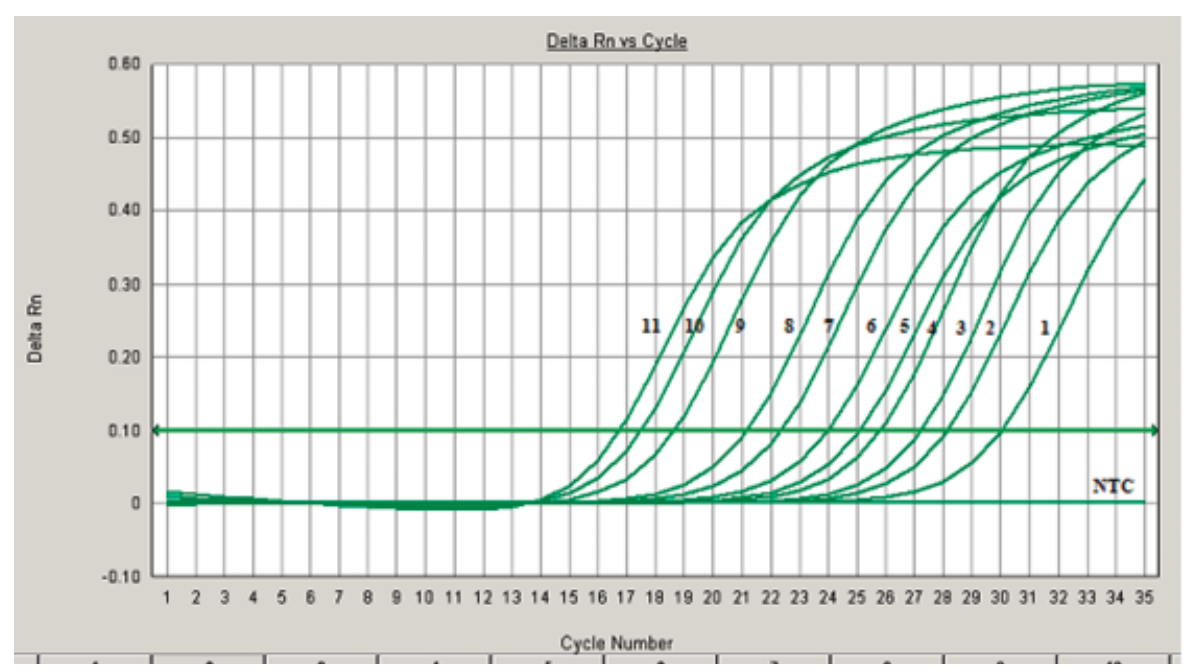

FIG. 5-Sensitivity of the human DNA quantification (H-Quant) assay. Two microliters of human DNA containing $5 \mathrm{pg} / \mu L$ (line 1), $10 \mathrm{pg} / \mu \mathrm{L}$ (line 2), 20 pg/ $\mu \mathrm{L}$ (line 3), $50 \mathrm{pg} / \mu \mathrm{L}$ (line 4), $0.1 \mathrm{ng} / \mu \mathrm{L}$ (line 5), $0.2 \mathrm{ng} / \mu \mathrm{L}$ (line 6), $0.5 \mathrm{ng} / \mu \mathrm{L}$ (line 7), $1.0 \mathrm{ng} / \mu \mathrm{L}$ (line 8), $5.0 \mathrm{ng} / \mu \mathrm{L}$ (line 9), $10.0 \mathrm{ng} / \mu \mathrm{L}$ (line 10), and $24.4 \mathrm{ng} / \mu \mathrm{L}$ (line 11) were amplified using the H-Quant assay reagents. NTC indicates no template control. The threshold value is indicated by a solid horizontal line with arrows. 
TABLE 1 -Concordance study between the developed H-Quant assay and the Quantifiler ${ }^{T M}$ human DNA quantitation kit.

\begin{tabular}{lcc}
\hline Sample & H-Quant $(\mathrm{ng} / \mu \mathrm{l})$ & Quantifiler $^{\mathrm{TM}}$ Human $(\mathrm{ng} / \mu \mathrm{l})$ \\
\hline 1 & 3.35 & 4.76 \\
2 & 8.10 & 9.79 \\
3 & 3.07 & 4.11 \\
4 & 3.59 & 5.03 \\
5 & 2.74 & 4.04 \\
6 & 2.34 & 3.58 \\
7 & 3.16 & 3.95 \\
8 & 3.78 & 6.13 \\
9 & 3.33 & 4.27 \\
10 & 1.73 & 2.09 \\
11 & 18.35 & 25.48 \\
12 & 19.75 & 30.46 \\
13 & 24.21 & 28.57 \\
14 & 0.922 & 0.172 \\
15 & 0.935 & 0.170 \\
16 & 1.15 & 0.203 \\
\hline
\end{tabular}

results were consistently higher than those run with the H-Quant assay, except for the samples containing $1.15 \mathrm{ng} / \mu \mathrm{L}$ or lower quantity of human DNA. The sizes of amplicons obtained from the H-Quant and Quantifiler ${ }^{\mathrm{TM}}$ human DNA quantitation system were 216 and 62 bases, respectively. Because the Quantifiler ${ }^{\mathrm{TM}}$ human DNA quantitation system detects a smaller amplicon, it is possible that this assay detects additional degraded DNA compared with the H-Quant assay that contributes to the higher values.

\section{Correlation with the Amplification of STRs}

Quantitation of human DNA in the biological samples is performed to determine the volume of extract for amplification of STR loci using multiplex genotyping systems. In general, 0.5$2.0 \mathrm{ng}$ of DNA provides an STR profile with allele peak heights
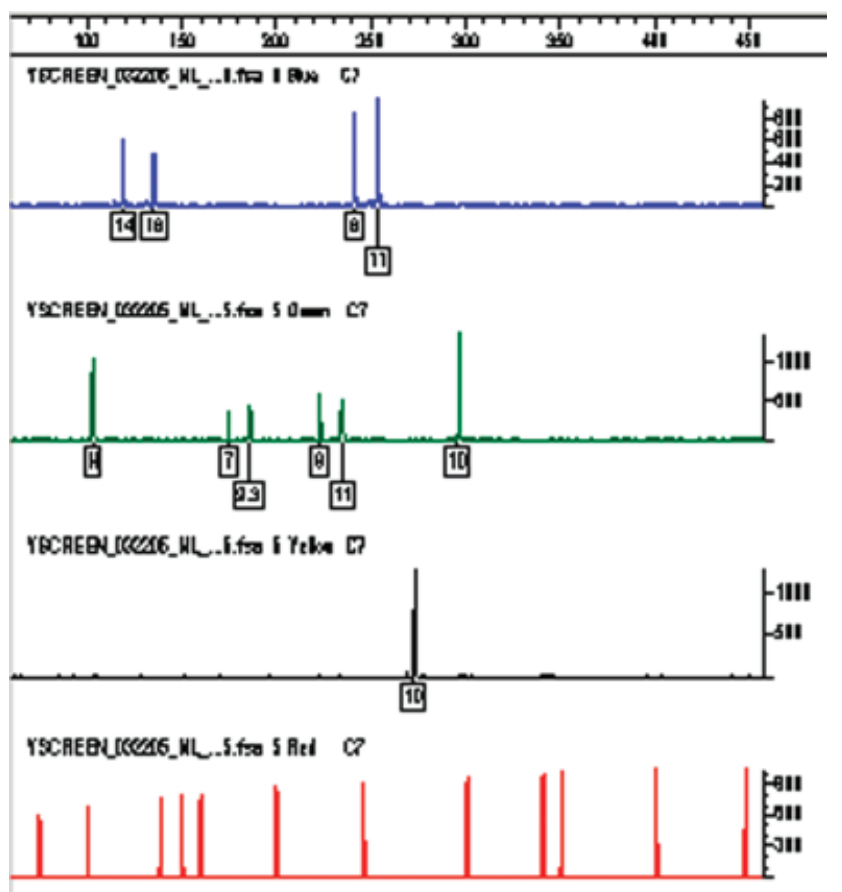

FIG. 6-Short tandem repeat (STR) profile for the $0.5 \mathrm{ng}$ of human DNA amplified with the AmpFlSTR ${ }^{\circledR}$ COfiler ${ }^{T M}$ and analyzed on a 3100 Genetic Analyzer. The quantity of DNA in the extract was determined by using the developed human DNA quantification (H-Quant) system. within the fractionation range and devoid of artifacts. The values of DNA quantitated by the H-Quant were correlated with the STR profile obtained using the AmpFlSTR ${ }^{\circledR}$ COfiler ${ }^{\mathrm{TM}}$ amplification kit. The profile obtained by amplification of $0.5 \mathrm{ng}$ of template DNA is presented in Fig. 6.

\section{Conclusions}

The quantity of human DNA in biological samples can be determined using the H-Quant system. The methods explore the realtime PCR principles for the quantitation of human DNA in unknown biological samples. The system's sensitivity was sufficient for quantification of as little as $7.6 \mathrm{pg} / \mu \mathrm{L}$ of human DNA. These data demonstrate that the H-Quant system is valid and reliable for quantitation of human DNA in forensic DNA analysis.

\section{Acknowledgments}

This research work was supported by the SBIR Grant \# GM61508 (S. K. S.), Louisiana Board of Regents Governer's Biotechnology initiative GBI (2002-005) (M. A. B.), National Science Foundation EPS-0346411 (M. A. B.), and the State of Louisiana Board of Regents Support Fund (M. A. B.). We thank Nikkia Lassere for her assistance in the correlation study, and Dr. Anthony Carter for reviewing the manuscript.

\section{References}

1. Fregeau CJ, Fourney RM. DNA typing with fluorescently tagged short tandem repeats: a sensitive and accurate approach to human identification. Biotechniques 1993;15:100-19.

2. Moretti TR, Baumstark AL, Defenbaugh DA, Keys KM, Smerick JB, Budowle B. Validation of short tandem repeats (STRs) for forensic usage: performance testing of fluorescent multiplex STR systems and analysis of authentic and simulated forensic samples. J Forensic Sci 2001;46:647-60.

3. LaFountain MJ, Schwartz MB, Svete PA, Walkinshaw MA, Buel E. TWDGAM validation of the AmpFlSTR profiler plus and AmpFlSTR COfiler STR multiplex systems using capillary electrophoresis. J Forensic Sci 2001;46:1191-8.

4. Krenke BE, Tereba A, Anderson SJ, Buel E, Culhane S, Finis CJ. Validation of a 16-locus fluorescent multiplex system. J Forensic Sci 2002;47:773-85.

5. Coble MD, Butler JM. Characterization of new miniSTR loci to aid analysis of degraded DNA. J Forensic Sci 2005;50:43-53.

6. Walsh PS, Varlaro J, Reynolds R. A rapid chemiluminescent method for quantitation of human DNA. Nucleic Acid Res 1992;20:5061-5.

7. Mandrekar MN, Erikson AM, Kopp K, Krenke BE, Mandrekar PV, Nelson R, et al. Development of a human DNA quantitation system. Croat Med J 2001;42:336-9.

8. Sifis ME, Both K, Burgoyne LA. A more sensitive method for quantitation of genomic DNA by Alu amplification. J Forensic Sci 2002;47:589-92.

9. Nicklas JA, Buel E. Development of an $A l u$-based, QSY 7-labeled primer PCR method for quantitation of human DNA in forensic samples. J Forensic Sci 2003;48:282-91.

10. Nicklas JA, Buel E. Development of an Alu-based, real-time PCR method for quantitation of human DNA in forensic samples. J Forensic Sci 2003;48:936-44.

11. Tringali G, Barbaro A, Insirello E, Cormaci P, Roccazzello AM. Rapid and efficacious real-time quantitative PCR assay for quantitation of human DNA in forensic samples. Forensic Sci Int 2004;146:S177-81.

12. Kochl S, Niederstatter H, Parson W. DNA extraction and quantitation of forensic samples using the phenol-chloroform method and real-time PCR. Methods Mol Biol 2004;297:13-30.

13. Alonso A, Martin P. A real-time PCR protocol to determine the number of amelogen $(\mathrm{x}-\mathrm{y})$ gene copies from forensic DNA samples. Methods Mol Biol 2004;297:31-44.

14. Green RL, Roinestad IC, Boland C, Hennessy LK. Developmental validation of the Quantifiler ${ }^{\mathrm{TM}}$ real-time PCR kits for the quantitation of human nuclear DNA samples. J Forensic Sci 2005;50:809-25.

15. Walker JA, Kilroy GE, Xing J, Shewale J, Sinha SK, Batzer MA. Human DNA quantitation using Alu element-based polymerase chain reaction. Anal Biochem 2003;315:122-8. 
16. Batzer MA, Deininger PL. Alu repeats and human genomic diversity. Nat Rev Genet 2002;3:370-9.

17. Carter AB, Salem AH, Hedges DJ, Nguyen-Keegan C, Kimball B, Walker JA., et al. Genome-wide analysis of the human Yb-lineage. Hum Genom 2004; 1:167-78

18. Budowle B, Smith J, Moretti T, DiZinno J. DNA typing protocols: molecular biology and forensic analysis. Natick: Eaton Publishing, 2000:41-2

19. DNA Advisory Board. Quality assurance standards for forensic DNA testing laboratories. Forensic Sci Commun 2000;2(3).

20. Henegariu O, Heerema NA, Dlouhy SR, Vance GH, Vogt PH. Multiplex PCR: critical parameters and step-by-step protocol. Biotechniques 1997;23:504-11.
21. Rybicki EP. A manual of online molecular biology techniques. 2005. Available at www.mcb.uct.ac.za/manual/MolBiolManual.htm

22. Singer VL, Jones LJ, Yue ST, Haugland RP. Characterization of PicoGreen ${ }^{\circledR}$ reagent and development of a fluorescence-based solution assay for double stranded DNA quantitation. Anal Biochem 1997;249:228-38.

Additional information and reprint requests:

Sudhir K. Sinha, Ph.D.

ReliaGene Technologies, Inc.

5525 Mounes St., Suite 101

New Orleans, LA 70123

E-mail: sinha@reliagene.com 